\title{
Translating Illocutionary Acts Implied in the Verb "know" (يَعْلَمُونَ) /yAAlamoon/ in the Translation of Meaning of the Glorious Quran
}

\author{
Mhmoud Abdelrahman Mustafa Abdelrahman \\ Doctorate of Philosophy in English Language (Tranlation) \\ E-mail: Mokhtar7979@yahoo.com
}

Received: December 13, 2019

Accepted: January 12, 2020

Published: January 16, 2020

doi:10.5296/elr.v6i1.16259

URL: https://doi.org/10.5296/elr.v6i1.16259

\begin{abstract}
The current study aims at investigating the verb "know" (يَعَُْمُونَ)/yAAlamoon/ in the translation of meaning of the Glorious Quran by Yusuf Ali, and exploring types and functions of illocutionary acts implied in the verb. The study claims that Quran translators face difficulties in rendering the implied meaning of the verb "know" (يَعََْمُونَ) /yAAlamoon/. The qualitative method has been adopted to analyze the content of the investigated verses. The results and discussion revealed the types and functions as well as the difficulties face translators when they translate the implied meaning of illocutionary acts.
\end{abstract}

Keywords: Pragmatics, Speech acts, Quran verse, Implied meaning

\section{Introduction}

Translation becomes challenging when the source text (ST) is the Holy Quran because the Holy Quran language has attributes necessitate translating the form and sense to the target text (TT). However, a good translator challenges the task and facilitates the act of communication between SL speakers/writers and TL hearers/readers. S/he is permitted greater freedom to interpret ST. The interpretation process will consequently clarify the implied pragmatic meaning, remove ambiguities, and even correct the author's factual errors. Interpreting the implied meaning of the Quran verses leads to discuss speech acts of utterances. These utterances carry more or different meaning than the semantic load of the words, because speech acts theory views communication as a series of communicative acts. These communicative acts are used systematically to accomplish particular communicative purposes. For a text such as the Glorious Quran, some styles, structures, or different communicative acts carry implied illocutionary meanings. These implied illocutionary 
meanings should be rendered by translators explicitly in order to present a clear and informative translated text.

\section{Statement of the Problem}

One of the difficulties in translating the Glorious Qur'an is that some styles and structures are Quran specific, and they do not have equivalents in English. Thus, when an attempt is made to translate these styles and structure into English, their original meaning could be lost because there are some illocutionary functions achieved by them in Arabic language. However, these functions need extra efforts to be rendered into English language due to the pragmatic, syntactic, and cultural differences between the two languages. An example of these styles and structures can be shown by the verb "know" (يَعْلَمُونَ) "yAAlamoon" in Quran verses. This verb carries illocutionary acts such as representative, directive, commissive, expressive, and declaration. However, sometimes functions of these acts are not achieved when translators translate Quran verses because they do not assume the implied meaning behind them and consequently meaning loss happens due to improper rendering. A clear example is the implied threatening which categorized under the commissive function of illocutionary acts is lost in the following verse translation:

(غافر (70)

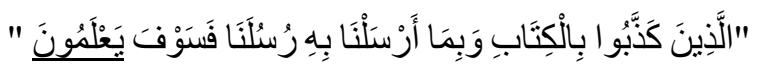

Transliteration: Allatheena kaththaboo bilkitabiwabima arsalna bihi rusulana fasawfayaAAlamoon.

Yusuf Ali: Those who reject the Book and the (revelations) with which We sent our messengers: but soon shall they know...

In relation to this research, some previous research was conducted to address the phenomenon. One of the studies is by Al Farisi who examines directive illocutionary acts that used in Quran, Chapter of Aal-Emran. Another study is by Mustafa Mahmoud who conducted a study aims at investigating the problems of translating the meaning of elliptic object in Quran.

This study adopts speech acts theory by Austin (1962) and Searle (1969) to analyze translated verses contain the verb "know" (يَعَكَمُونَ) "yAAllamoon". The theory is used to extract meaning implied and the illocutionary messages of the investigated verb.

\section{Significance of the Study}

Three points or reasons show the significance of this study:

1) This study is about the translation of the meaning of the Holy Quran, and it is supposed to be presented for English language speakers in general and new Muslim converts in particular.

2) Investigating the translation of some problematic object ellipsis structures refute non-Muslims and new Muslim converts misunderstanding that results from generating more than one acceptable meaning, if there are any, by drawing attention to this phenomenon and explaining the reasons behind it.

3) The study analyzes the selected verb translation semantically and pragmatically in order to identify the problems that face translators in rendering it. Such problems could lead to errors or ambiguity in the given translations. Therefore, the study attempts to find out the 


\section{MInstitute Macrothin}

problems in order to avoid committing errors and suggest solutions to these problems. These solutions hopefully help future translators avoid misrepresentations of the linguistic and rhetorical functions of syntactic structures.

\section{Research Objectives}

The study specifically aims at the following:

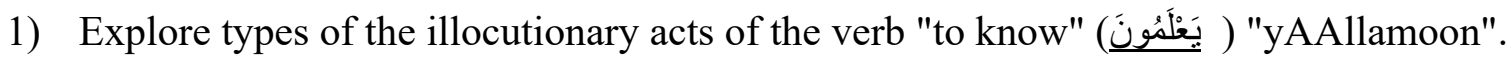

2) Identify functions of the illocutionary acts of the verb "to know" (يَعَفَكُونَ ) "yAAllamoon".

3) Investigate how Ali's translation of meaning of the Glorious Quran delivers the illocutionary functions implied in the verb (يَعَفَمُونَ ) "yAAllamoon" "to know".

\section{Research Questions}

Based on the objectives of the present study, the research questions are as follows:

1) What are the types of the illocutionary acts of the verb "to know" (يَعْلَكُونَ) "yAAllamoon"?

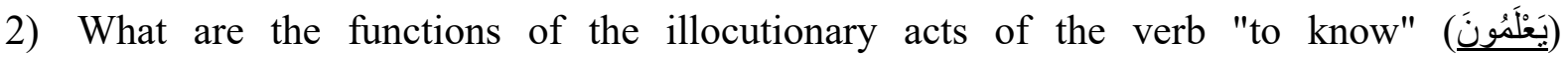
"yAAllamoon"?

3) To what extent did Ali's translation succeed in delivering the illocutionary functions

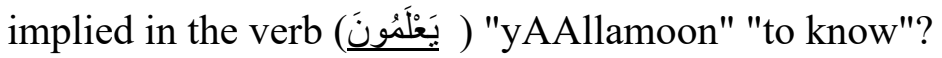

\section{Research Methodology}

In this research, the qualitative method has been used. This method is a research design that uses qualitative data to deduce facts out of texts. Also, the researcher has used content analysis to analyze data. In addition, the researcher collects the study data manually from the Glorious Quran and the English translation of the Glorious Quran by Yusuf Ali. The data have been searched, sorted, and collected from the Glorious Quran thematically. The researcher has collected and identified the frequentative functions of illocutionary acts of the verb "know" (يَعَلْمُونَ) "yAAlamoon" in Quran verses which carries illocutionary functions such as representatives, directives, commissives, expressives, and declaration. The first step the researcher has searched the most frequentative types. The second step the researcher has sorted to see the most frequentative functions. The collected data in this research have been classified and analyzed based on speech acts theory and the illocutionary functions by Searle classification. The investigated verb is found in 95 verses at the end of the verse in 31 chapters. The verb at the end of verses only has been investigated due to meaning ambiguity. At the same time, the most problematic ones has been concentrated on. Table no 1 , page no 4 shows the corpus of the study.

Table 1 . The corpus of the study

\begin{tabular}{lll}
\hline Serial & Chapter & Verse No \\
\hline 1 & Al-Baqara & $13,22,30,42,75,80,102,103,146,151,216,232$ \\
2 & Ali Emran & $66,71,75,78,135$ \\
3 & Alanaam & $37,67,81,97$ \\
4 & Al- Araf & $28,32,28,33,38,62,123,131,187$ \\
\hline
\end{tabular}




\begin{tabular}{lll}
\hline 5 & Al-Anfal & 34 \\
6 & At-Tawba & $11,16,41,93,105$ \\
7 & Yunus & $5,55,68$ \\
8 & Yusuf & $21,40,46,86,96$ \\
9 & Al-Hijr & 3 \\
10 & Al-Nahl & $8,38,43,55,74,75,95,101$ \\
11 & Al-Anbiaa & 7 \\
12 & Al-Mumenoon & $84,88,114$ \\
13 & An-Noor & 19 \\
14 & An-Naml & 52,61 \\
15 & Al-Qasas & 13,57 \\
16 & Al-Ankaboot & $8,16,41,64,66$ \\
17 & Ar-Room & $6,30,34,56,59$ \\
18 & Lugman & 15,25 \\
19 & Saba & 28,36 \\
20 & Yasine & 26,36 \\
21 & Az-Zumar & $9,26,29,39,49$ \\
22 & Ghafir & 57,70 \\
23 & Fussilat & 3 \\
24 & Az-Zukhruf & 89 \\
25 & Al-Dukhan & 39 \\
26 & Al-Jathia & 18,26 \\
27 & At-Tur & 47 \\
28 & Al-Waqia & 61 \\
29 & Al-Mujadila & 14 \\
30 & As-Saf & 11 \\
31 & Al-Jumua & 9 \\
\hline
\end{tabular}

Names of Chapters and number of verses that contain the investigated verb "know" (يَعَكَئمنَ) "yAAlamoon"

\subsection{Steps Followed to Conduct the Study}

To guarantee the validity and reliability of the study, the following steps were taken be the researcher: 
1) Ninety-five of Quran verses were investigated in this study. However, fourteen out of them were displayed in the study as models. Although the ninety-five verses were not displayed in the study, their numbers and chapter were mentioned in the study.

2) These Quranic verses were transliterated from Arabic into English.

3) Ali's translation of each Quranic verse meaning was presented.

4) The investigated verbs in verses were quoted, numbered, and underlined.

5) Different interpretations of each verse concerned with the translation under study were compared and came up with an accurate meaning of each verb to see if the existing translation under investigation didn't give the intended meaning and the accurate translation.

6) Different accurate authentic classical and modern exegeses, views of different linguists and translation theories, classical Arabic-Arabic dictionaries, English dictionaries, and encyclopedias were consulted.

7) The interpretation of each verse were analyzed according to the context, the situation in which the verses were revealed, and the reasons for revealing these verses to Prophet Mohammed (PBUH).

8) The given translation were not re-translated, but it was suggested to what extent the translation is suitable in terms of dealing with the implied meaning by giving comments on it.

9) seven researchers of two majors (Linguistics and Islamic Studies) were consulted about the steps taken to analyze the collected data.

10) The feedback provided by the researchers was considered by confirming the positive ones and rectifying the negative ones.

\section{Theoretical Framework}

\subsection{Pragmatics}

This study tries to investigate how translators of the meaning of the Glorious Quran deal with the intended meaning of the verb "know" (يَعْلَمُونَ) /yAAllamoon/. The translator should hence follow a process of a pragmatic analysis or search for the intention of the implied meanings of the investigated verb. Definitely, this is because literal translation or word-for-word translation would result in a naive translation that does not deliver the implied meaning or the function hidden in the surface meaning.

Many different scientific theories and approaches have been developed to understand the Glorious Quran. One of them is pragmatics which connects between language form and users. It is also interested in languages and their relation with the contextual background features. "Pragmatics is about how the listener interprets utterances and the speaker produces interpretable utterances" (Griffiths, 2006). Another linguist who also defines pragmatics is Leech. "Pragmatics is a study of meaning related to speech situation" (Leech, 1983).

In Quran translation, translators should be familiar with the difference between semantic meaning and pragmatic meaning. In this study, although the researcher focuses on pragmatic meaning, he displays what can serve the study from the semantic meaning. In fact, they both deal with meaning but differ in the way they consider the type of meaning. Pragmatic meaning is focusing on the way pragmatic factors link linguistic structure to linguistic usage. 
It is as confirmed by Hatim and Mason "pragmatic meaning would provide the translator with insights into intentionality (The intended meaning)" (Hatim \& Mason, 1997).

Pragmatic meaning leads to pragmatic or communicative translation. "Pragmatic translation is the kind of translation which pays attention not only to denotative meaning but also to the way utterances are used in communicative situations and the way we interpret them in context" (Shuttelworth-Cowie, 2007). In other words, pragmatic translation takes into account connotative meaning, allusion, and interpersonal aspects of communication. Since the two most important pragmatic phenomena that carry pragmatic meaning are speech acts and indirectness, the researcher devote the following parts to present some necessary information about pragmatics and speech acts theory.

\subsubsection{Speech Acts Theory}

Speech acts theory was introduced by Austin in 1962 and developed by Searle in 1969. Austin (1962) argues that about speech acts "we often do things with words, when we use them to perform actions such as promising, welcoming, boasting, affirming, advising, etc"(p. 12). Searle (1969) proposes that "speech acts are the basic units of communication" (p. 21). Peccei (2005) states that "speech act is a human activity in language, it studies the way people act through their speech"(p. 43). Basically, in speech act, uttering of a sentence is an action within the framework of social surroundings. In languages generally and the Glorious Quran particularly, speech acts are used systematically to accomplish particular communicative purposes. Also, speech acts carry more or different meaning than the semantic meaning of the words. Thus, when translators render Quran, they should give the word meaning, the contextual meaning, and the utterance force the same interest.

Austin (1967) distinguished three actions performed by language users while producing an utterance: locutionary act, illocutionary act, and perlocutionary act.

1) Locutionary act is performed by uttering a meaningful sentence.

2) Illocutionary act shows the communicative force of an utterance. It can be performed via different acts for instance: "I talked to Mr. John today and I talked to your doctor today". That means the listener's doctor is called John. Sometimes the same locutionary act can realize different illocutionary acts as "you will know" can function as a warning, promise, or prediction. From the previous point, we can say that the same locutionary act can have different illocutionary forces in different contexts depending on the surroundings.

3) Perlocutionary act shows the effect of the utterance on the hearer or reader. It is performed through the impact of using illocutionary acts. More technically, a perlocution is the act by which the illocution produces a certain effect or influence on the addressee.

\subsubsection{Illocutionary Functions}

The Glorious Quran has various forms of messages i.e. commanding, prohibition, threat, etc. Therefore, no wonder to analyze the Glorious Quran by applying speech acts theory specifically illocutionary acts because the Quran is full of such acts for human. Austin (1962) states that "illocutionary acts are acts performed in saying something". Austin provides his categories (his five speech acts) very tentatively, as a basis for discussion more than as a set of established results. He says (I962) "I am not putting any of this forward as in the very least definitive. I think they form an excellent basis for discussion but I also think that the 
taxonomy needs to be seriously revised because it contains several weaknesses"(p. I5I). Here are Austin's five categories:

1) Verdictives: These consist in the delivering of a finding, official or unofficial, upon evidence or reasons as to value or fact so far as these are distinguishable.

2) Exercitives: One of these is the giving of a decision in favor of or against a certain course of action or advocacy of it.

3) Commissives: The whole point of a commissive, Austin tells us that it is to commit the speaker to a certain course of action.

4) Expositives: They are used in acts of exposition involving the expounding of views, the conducting of arguments and the clarifying of usages and reference.

5) Behabitives: This class includes the notion of reaction to other people's behavior and fortunes and of attitudes and expressions of attitudes to someone else's past conduct or imminent conduct.

On the basis of Austin's classification, Searle (1965) promoted his kinds. They are as follows: 1). Representatives / Assertive: This act explains the situation, which commits the speaker to the truth of the expressed proposition such as asserting, concluding, announcing, and predicting.

2). Directives: The objective of this act is to make the addressee do something. The examples are direct, advice, urge, supplicate, implore, entreat, beseech, pray, tell (to), require, ask, beg, suggesting, command, recommend, demand, order, request, and forbid. For example:

3). Commissives: This act is aimed at urging the addresser to do something, such as promising, swearing, threatening, and offering.

4). Expressives: This act expresses the addresser's psychological state as thanking, apologizing, welcoming, praising, and congratulating. Like the commissives, they tend to be convivial and therefore intrinsically polite. The reserve is true, however, of such expressive as 'blaming' and 'accusing'.

5). Declaration: This act is used to uphold a particular speech act that affect immediate changes in the institutional state of affairs and which tend to rely on elaborating extra linguistic institution as declaring war, excommunication, christening, appointing, and firing from employment.

Some other linguists have classified some categories of illocutionary acts. Cutting (2000), introduces five classifications i.e. declaration, representatives, commisives, directives and expressives. Also, the Searle's categorization is adopted by Yule. His categorization is that "illocutionary speech acts also can be divided into five types. They are as follows: declaratives, representatives, expressives, directives, commissives" (Yule, 1996). However, Leech (1983), adopts a different categorization. Four categories are adopted by Leech. They are according to how they relate to the social goal of establishing and maintaining comity. The four types of illocutionary acts functions as follows:

1) Competitive aims at competing with the social purpose, such as ordering, asking, demanding, and begging. 
2) Convivial aims at compliance with the social purposes, for instance offering, inviting, greeting, thanking and congratulating.

3) Collaborative aims at ignoring the social purposes as like asserting, reporting, announcing, and instructing. It is commit the speaker to the truth of expressed proposition.

4) Conflictive aims at conflicting against the social purposes. Such as threatening, accusing, and reprimanding.

\subsection{English Language and Arabic Language Speech Acts}

Before going deep into explaining the relation between speech acts and Quran translation, some concepts belong to English and Arabic speech acts should be explained. Firstly, the primary meaning or locutionary, and the secondary meaning or illocutionary of utterances should be considered. To be more accurate, the point that the study of locutionary force is semantic, whereas the study of illocutionary force pragmatic. Both forces should be put in mind during translation because they vary in difficulty. In other words, the primary meaning needs less effort than the secondary meaning. Secondly, performative and constative utterances should be raised to know their equivalence in Arabic language because they are totally different. Constative utterances describe some events, processes or state-of-affairs, and they can be considered either true or false. Performative utterances have nothing to do with truth-value because they are used to do something rather than to say true or false things. Austin (1962) distinguishes between performatives and constatives by arguing that: "constatives are propositions which can be stated positively or negatively, i.e., they are statements of facts which could be right or wrong. Unlike constatives, performatives are formulated, under appropriate conditions not to describe something but to achieve something". So, later, Austin abandoned his original distinction between performative and constative utterances replacing them with that between primary performatives and explicit performatives. He gives the name primary performatives to illocutionary ambiguous utterances and the term explicit performatives for utterances introduced by a prefix indicating without ambiguity to their illocutionary force. Among the distinction between primary and explicit performatives, the most important point which serves this study is that English makes frequent use of implicit or primary performatives, whereas Arabic tends more often to use explicit performatives. "As a general Arabic tends to be more explicit than English; what is implicit in English often has to be spelled out in Arabic" (Emery, 1986). This why the Arabic/English translator should make an important shift form implicit to explicit performatives or vice versa. Definitely, the shift depends on the translation flow.

On the contrary, structurally, Arabic has two major types of utterances. They are declarative utterances and performative utterances. They cover all structures and forms of speech whether poetry or prose, etc. Declarative utterances are those utterances which are liable to assessment in terms of truth or falsity while performative utterances are defined as those utterances which are not liable to assessment in terms of truth or falsity.

To make the matter clearer, the performative utterances as opposed to declarative utterances, will be investigated with regards to the Quran from the Arabic point of view. Their two types locutionary force and illocutionary force. 
Arab rhetoricians divide the performative utterances into two basic types: demand or rogative performatives that serve to express requests, non-demand or non-rogative performatives. Non-rogative performatives such as contractual formula to express acceptance of a bargain, expression of astonishment, oaths, and expressions of praise or blame. This type doesn't affect Quran translation too much rhetoricians because it lacks any rhetorical purpose. On the contrary, demand performative utterances which are mainly rhetorical should receive much attention during translation.

Demand performative utterances have five main subtypes. These are: imperative, negative imperative, interrogative, vocative, and wish. As explained earlier, only the types that serve this study the most will be discussed. Therefore, only the imperative, negative imperative, and interrogative will be discussed if there is any case, specifically their secondary meanings because they are the most important thing for the Quran translators. In fact, there are many secondary meanings for the imperative form such as challenge, continuation, supplication, threat, scorn, permission, equalization. Regarding the secondary meanings of the negative imperative, they can be as follow: continuation, denial of hope, advice and guidance, supplication, petition, while the secondary meanings of the interrogative are: exclamation, order, negation, improbability, inducement and fascination, negative, scorn and mockery, expression of awe and exaltation, wish, affirmation, and disaffirmation.

The researcher confirms that one of the difficulties that faces this study is that illocutionary force is misleading since it suggests that different illocutionary forces occupy different positions on a single continuum of force. Moreover, Some few verbs mark more than one illocutionary point, e.g. a protest involves both an expression of disapproval and a petition for change. Promulgating a law has both a declaration status (the propositional content becomes law) and a directive status (the law is directive in intent).

\subsection{Equivalence}

There are three major types of equivalence provided by translation theories. These are formal, dynamic, and functional. Formal equivalence gives priority to form (syntax), but not at the expense of content. Dynamic equivalence, on the other hand, has been developed to productively take care of what formal equivalence neglects. Functional equivalence is the result of the progress achieved in the field of text linguistics. Its establishment results from the analysis of the whole text, each as a unit connected to what precedes and what follows. The researcher adopts functional equivalence as a suitable approach to the rendition of speech acts. Between English and Arabic.

\section{Literature Review}

In relation to this research, some previous studies were conducted to address the pragmatic meaning of the Glorious Quran. One of these studies was conducted by Kadhim (2007). The study mentions that Quranic verses are full of pragmatic utterances in which messages are expressed in forms not usually used for those purposes, i.e., in some cases, question-type utterances are used not to ask for information but to warn people of their misbehavior and what consequences they might expect otherwise. According to Kadhim (2007), this can be noted in following verse where a rhetorical question is used as a linguistic form expressing the speech act of prohibition 


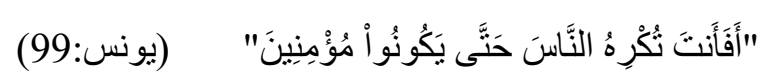

Transliteration: afaanta tukrihu annasahatta yakoonoo mu/mineen...

Yusuf Ali: "Wilt thou then compel mankind against their will, to believe! (Yunus: 99)

Hammoodah (1983, p.67) states that: "examples can be found showing the speech act of "command" realized by the declarative clause". It is as in the following verse.

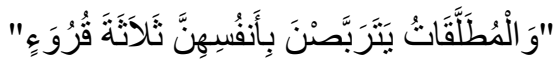

Tramsliteration: Walmutallaqatuyatarabbasna bi-anfusihinna thalathata quroo-in...

Muhsin Khan: And divorced women shall wait (as regards their marriage) for three menstrual periods,...(Al-Baqara: 228)

Al-Farisi (2018) examines directive illocutionary acts that used in Quran, Chapter of Aal-Eimran. The study focuses on types of directive illocutionary acts used, the most frequently type of directive illocutionary acts used and their functions. It uses a descriptive qualitative design. The data are taken from a translated text of Chapter of Aal-Eimran by Abdel Haleem. The result shows that the writer found six types of directive illocutionary acts that used in Quran especially surah Aal-Eimran. Al-Farisi (2018) mentions the following verse of Chapter of Aal-Eimran is a directive illocutionary act. It prohibits and explains that Allah forbid people especially Muslims who spread out around the world or the reader of the Glorious Quran not to have doubt about the almighty of God and if they have doubts, Allah will get angry of people like this.

( 60 (آل عمر ان

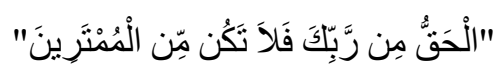

Transliteration: Alhaqqu min rabbika fala takunmina almumtareen...

Yusuf Ali: The Truth (comes) from Allah alone; so be not of those who doubt... (Aal-Eimran:60)

Another study was conducted by Mustafa (2019). The study aimed at investigating the problems of translating the meaning of elliptic object to refute the vast mass of misinterpretations of problematic elliptic objects, and investigating theories and models used in translating the elliptic object. Mustafa Mahmoud (2019:124) states that "Although elliptic elements of the Quran verses are assumed and explained in exegeses automatically, some translators do not render these utterance forces explicitly". The study follows the analytical descriptive method. It depends on drawing qualitative data from three translations by Ali, Muhsin, and Picthall. The study has found out several results as follow: the translators of the three investigated translations have sometimes assumed the meaning of elliptic object explicitly, whereas ignored it in other situations. The study has attributed these problems to the reliance on theories and techniques that do not suit translation of the syntactic items. Mustafa (2019) sees that not assuming the elliptic object explicitly creates more than one meaning and consequently confuse receivers. In verse no (15) of Chapter Al-Ala, the meaning of the omitted object of the verb (فَصَّلَّى) / fasalla/ "pray" is assumed by Khan, but isn't assumed by Ali and Pickthall. According to Ibn Katheer (2009,p.2502), "pray means five compulsory prayers and Nawafil (additional prayer)". The researcher thinks that Khan perfectly succeeds in conveying the meaning of this verse. Generalizing the meaning of the word "pray" by Ali and Pickthall generates a different meaning compared with Khan's. 
(الاعلى-15)

Transliteration: Wathakara isma rabbihi fasalla.

Muhsin Khan: And remembers (glorifies) the Name of his Lord (worships none but Allah), and prays (five compulsory prayers and Nawafil additional prayers.

Yusuf Ali: And glorify the name of their Guardian-Lord, and (lift their hearts) in prayer.

Pickthall: And remembereth the name of his Lord, so prayeth,...

A lot of Arab rhetoricians such as Al-Askari (1964), Al-Jerjani (1977), and Al-Sekaki (1980) explained constative and performative utterances. According to them, constative is an utterance in which a speaker issues his utterance to tell his addressee something. On the other hand, performative is that kind of meaning in which the speaker asks his addressee to do something as shown in the following verse of Chapter An-Noor.

$$
\text { (56: النور ) }
$$

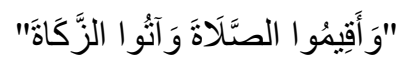

Transliteration: Waaqeemoo assalata waatooazzakata...

Yusuf Ali: So establish regular prayer and give regular charity. (An-Noor:56)

\section{Results and Discussion}

The Quranic verses sometimes carry commands, prohibitions, and threats which are considered as speech acts used by Allah to send messages. Thus, pragmatics with its own method has offered a certain way to understand the messages in Glorious Quran. Analyzing this study pragmatically necessitates studying primary performatives and explicit performatives. Both should be considered when the Quran translators translate the Arabic utterances, especially performative ones with their secondary meanings. Moreover, during Quran translation, consulting the authentic exegeses is a must for the translator to understand the illocutionary messages. At the same time, s/he must be highly competent at English language and pragmatics. In this case, two options are permissible for translators. The first option is to try to transfer the pragmatic flavor of the source text into the target text. The second option which is preferable to the researcher is to declare the meaning explicitly. The preference results from that the translator is unfamiliar with the level of the receiver, and whether s/he understands the message perfectly or not. In other words, the second option is recommended due to its explicitness and appropriateness of all levels.

By referring to the investigated translations, it is clear that the Glorious Quran translators do not deal with the secondary meanings perfectly. In other words, they need to exert more effort to deliver the exact intended meaning of the problematic verses which contain the verb "know" (يَعَمَكُونَ) /yaAAlamoon/.The following investigated verses show the most frequentative types of illocutionary acts of Searle classification. Also, they show to what extent the Ali's translation could deliver the functions behind the implied meaning of the illocutionary utterances. The researcher would like to stress that the investigated verses which are displayed in this study are the most problematic ones.

\subsection{Representatives / Assertive}

The purpose of this act is to commit the speaker to a certain case, or to the truth of the expressed proposition such as asserting, concluding, announcing, and predicting. It can be assessed true or false. The main function of assertive speech acts contained in the 
investigated Quranic verses of the verb "know" (يَعَلَمُونَ)/yaAAlamoon/ in this study carried out when Allah Almighty expresses and informs the reader of The Glorious Quran some information as shown in the following five verses.

Verse No (1)

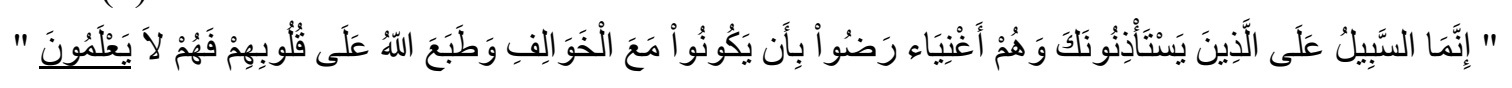

Transliteration: Innama assabeelu AAalaallatheena yasta/thinoonaka wahum aghniyaoradoo bi-an yakoonoo maAAa alkhawalifi watabaAAaAllahu AAala quloobihim fahum la yaAAlamoon.

Yusuf Ali: The ground (of complaint) is against such as claim exemption while they are rich. They prefer to stay with the (women) who remain behind: Allah hath sealed their hearts; so they know not (What they miss)

In verse no (93) of Chapter At-Tawba, Ali have delivered the intended meaning of the verb ( يَعْلَمُونَ) /yaAAlamoon/ "know" explicitly. "Their loss" (Tafseer Al-Jalalayn, 2007). The meaning is assumed as "حجم خسارتهم" "their loss"(Ibn Katheer, 2009, p.808). As it is shown above, Ali has dealt with this verse perfectly, and he has declared the implied meaning of the investigated verb.

Verse No (2)

(النحل-101 )

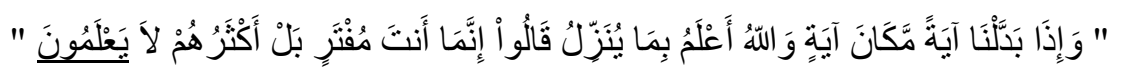

Transliteration: Wa-itha baddalna ayatanmakana ayatin wallahu aAAlamu bimayunazzilu qaloo innama anta muftarin bal aktharuhumla yaAAlamoon

Yusuf Ali: When We substitute one revelation for another,- and Allah knows best what $\mathrm{He}$ reveals (in stages),- they say, "Thou art but a forger": but most of them understand not.

In verse no (101) of Chapter An-Nahl, Ali hasn't assumed the implied meaning of the verb ( لَعْلَمُونَ) /yaAAlamoon/ "know or understand" explicitly. The meaning has been assumed as "to know the reality of the Glorious Quran and the benefit brought about by abrogation"(Tafseer Al-Jalalayn, 2007). By referring to Ali's translation, he has preferred implicity to explicity. Fortunately, the act of this verb is a representative one, and it doesn't create a big problem to the receiver. However, assuming the meaning explicitly makes the translation more informative.

Verse No (3)

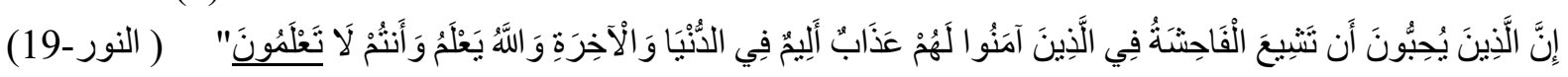
Transliteration: Inna allatheena yuhibboona antasheeAAa alfahishatu fee allatheena amanoolahum AAathabun aleemun fee addunya wal-akhiratiwallahu yaAAlamu waantum la taAAlamoon

Yusuf Ali: Those who love (to see) scandal published broadcast among the Believers, will have a grievous Penalty in this life and in the Hereafter: Allah knows, and ye know not.

Verse no (19) of Chapter An-Noor is about a famous incident in the prophet life peace be upon him. It is about the fabricated story of Al-Ifk "slander" when Allah revealed verses to prove the innocence of the prophet's wife Aisha. By referring to the translation, Ali hasn't assumed the implied meaning of the verb (تَعْلَمُونَ) / taAAlamoon/ explicitly. In Tafseer 
Al-Jalalayn (2007), it has been assumed as " تعلمون بر اءة السيدة عائشة رضي الله عنها " Allah knows that they are innocent of this shameful crime (Aisha and Safuan)" (p.1018). The translators' insistence on the generalization of some verbs leads to miss very important information. The researcher thinks that this information carries the essence of translation. Therefore, the researcher insists on assuming the implied meaning explicitly.

Verse No (4)

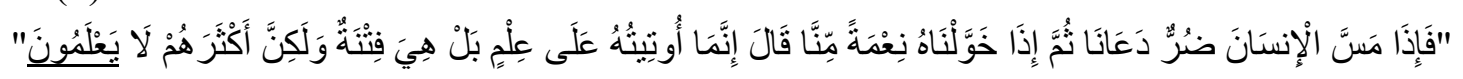

(49- (الزمر (1)

Transliteration: Fa-itha massa al-insana durrundaAAana thumma itha khawwalnahuniAAmatan minna qala innama ooteetuhu AAalaAAilmin bal hiya fitnatun walakinna aktharahum layaAAlamoon

Yusuf Ali: Now, when trouble touches man, he cries to Us: But when We bestow a favour upon him as from Ourselves, he says, "This has been given to me because of a certain knowledge (I have)!" Nay, but this is but a trial, but most of them understand not!

The implied meaning in the underlined verb of verse 49 of Chapter Az-Zumar has been assumed by (Tafseer Al-Jalalayn, 2007; Ibn Katheer, 2009) as most of the straying do not know the favors are given to them as a trial and a test for them. Therefore, the assumption is "this grant is a test". Ali's translation hasn't assumed the implied meaning explicitly. However, the researcher recommends translators to convey meaning clearly as they don't know the academic level of receivers.

Verse No (5)

$$
\text { (3-3) }
$$

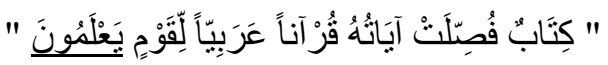

Transliteration: Kitabun fussilat ayatuhuqur-anan AAarabiyyan liqawmin yaAAlamoon

Yusuf Ali: A Book, whereof the verses are explained in detail;- a Qur'an in Arabic, for people who understand...

In verse 3 of Fussilat Chapter, Ali hasn't assumed the meaning of the verb (يَعْلَمُونَ) / yaAAlamoon/ "know or understand" explicitly. Ibn Katheer (2009) mentions that "it is that only well-versed scholars are those acquire this clear and detailed style"(p. 1964). In Tafseer Al- Jalalayn (2007) "due to its being such a clear Arabic Quran, its meanings are explicitly detailed and its words are too expensive having nothing confusing"(p. 1363). The researcher thinks that the meaning implied behind the investigated verb should be assumed as البيان و هeatness and clearness of Quran style". Definitely, no assuming the implied meaning of the investigated verb made the translation less informative.

Table 2. Names of Quran chapters and numbers of assertive illocutionary acts

\begin{tabular}{lll}
\hline Serial & Chapter & Verse No \\
\hline 1 & Al-Baqara & $13,22,28,30,42,75,80,102,146,151,232$ \\
2 & Ali Emran & $66,71,75,78,135$ \\
3 & Alanaam & $37,81,97$ \\
\hline
\end{tabular}




\begin{tabular}{lll}
\hline 4 & Al- Araf & $32,33,62,131,187$ \\
5 & Alanfal & 34 \\
6 & At-Tawba & $11,93,105$ \\
7 & Yunus & 5,55 \\
8 & Yusuf & $21,40,46,86,96$ \\
9 & Al-Nahl & $8,38,43,74,75,101$ \\
10 & Al-Anbiaa & 7 \\
11 & Al-Mumenoon & $84,88,114$ \\
12 & An-Noor & 19 \\
13 & An-Naml & 52,61 \\
14 & Al-Qasas & 13,57 \\
15 & Al-Ankaboot & $8,16,41,64$ \\
16 & Ar-Room & $6,30,56,59$ \\
17 & Lugman & 15,25 \\
18 & Saba & 28,36 \\
19 & Yasine & 26,36 \\
20 & Az-Zumar & $9,26,29,39,49$ \\
21 & Ghafir & 57 \\
22 & Fussilat & 3 \\
23 & Al-Dukhan & 39 \\
24 & Al-Jathia & 18,26 \\
25 & At-Tur & 47 \\
26 & Al-Waqia & 61 \\
27 & Al-Mujadila & 14 \\
28 & As-Saf & 11 \\
\hline
\end{tabular}

Names of Quran chapters and page numbers of verses that carry assertive illocutionary acts implied in the investigated verb "know" (يَعْلَمُونَ) /yaAAlamoon/ among the investigated verses

As mentioned before, the researcher determines the implied meaning of illocutionary acts, and how the Quran translators deal with. It is clear that Yusuf Ali does not find any difficulty in translating and conveying the assertive illocutionary acts of the verb (يَعَلَمُونَ) /yaAAlamoon/ "know" because he assumes the implied meaning in many situations. However, inconsistency on one translation method makes the translation informativity varies between more and less informative. The table below displays the investigated verses that contain the verb(يَعْلَمُونَ)/yaAAlamoon/ "know" which carry representative acts. 


\subsection{Directives}

The objective of this act is to make the addressee do something. The examples are direct, advice, urge, supplicate, implore, entreat, beseech, pray, tell (to), require, ask, beg, suggesting, command, recommend, demand, order, request, and forbid.

Verse No (1)

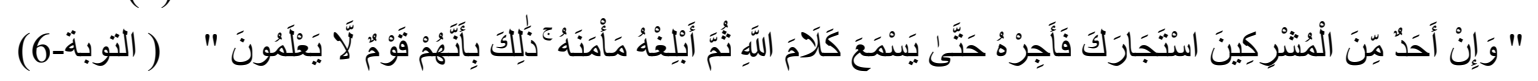

Transliteration: Wa-in ahadun mina almushrikeena istajarakafaajirhu hatta yasmaAAa kalama Allahithumma ablighhu ma/manahu thalika bi-annahum qawmun layaAAlamoon.

Yusuf Ali: If one amongst the Pagans ask thee for asylum, grant it to him, so that he may hear the word of Allah; and then escort him to where he can be secure. That is because they are men without knowledge.

As for some directive speech functions delivered by the translator based on the context, verse no 6 Chapter At-Tawba, Ali, has not delivered the implied meaning of the verb (يَعْلَمُونَ) /yaAAlamoon/ perfectly. "Without knowledge" which was presented by Ali, shows unclear meaning although the meaning behind the verb has been assumed by many exegeses as ( "Islam or Islam teachings". Conveying the translation as "without knowledge of Islam teachings" explicitly, explains that Almighty Allah command or ask to excuse the disbelievers because they do not know the Islam teachings.

\subsection{Commissives}

Commissives are those kinds of speech acts that speaker use to commit themselves to some future actions. They express speaker's intention. They are promises, threats, refusals, and pledges, and they can be performed by the speaker alone or by the speaker as a member of a group. Yule (1996) mentions that "in using a commissives, the speaker undertakes to make the world fit the words (via the speaker)" (p.54). According to Searle (1967), there are six categories of commissive speech acts, i.e. promise, guarantee, refusal, threat, offer, and volunteer. The following seven verses show two functions of commissive acts. They are "threatening and warning" and " inducement and fascinating" as follows:

Verse No (1)

( الحجر-96)

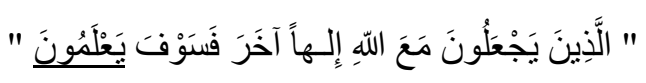

Transliteration: Allatheena yajAAaloona maAAa Allahiilahan akhara fasawfa yaAAlamoon.

Yusuf Ali: Those who adopt, with Allah, another god: but soon will they come to know.

According to Ibn Katheer (2009), verse no (96) of Chapter Al-Hijr "implies such a stern threat and affirmed warning for those who ascribe others in worship along with Allah"(p.1070). This view also is enhanced by Tafseer Al-Jalalayn (2007) as "those who ascribe others in worship along with Allah will surely come to know the end of what used to do of trespassing, transgressing, disbelief and polytheism"(p.764). The translator translates it as (will come to know) without assuming the implied meaning (threatening) of the verb ( نَعْلَمُونَ) / yaAAlamoon / " know". He tried to convey the secondary meaning of the verse "threat and warning" through speech acts, but he was unclear. Definitely, it is not easy to convey linguistic functions from one language to another because languages are different structurally and culturally. Therefore, supporting the idea of assuming the implied meaning of 
the investigated verb as (يعلمون ضلالهم) "know they are in the wrong path", and declaring " warning and threat" explicitly in order not to lose the meaning is a must.

Verse No (2)

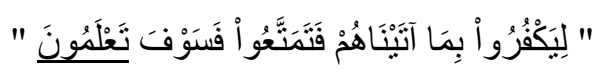

Transliteration: Liyakfuroo bima ataynahumfatamattaAAoo fasawfa taAAlamoon.

Yusuf Ali: (As if) to show their ingratitude for the favours we have bestowed on them! then enjoy (your brief day): but soon will ye know (your folly!)

In verse no (55) of Chapter An-Nahl, the implied meaning of the verb (تَعَمَكُونَ) / taAAlamoon / "know" is assumed as "سوف تعلمون عاقبة ما ارتكبتم"you will come to taste the consequence of that you commit" (Ibn Katheer 2009,p.1094). Also, in Tafsser Al-Jalalayn (2007), it is assumed as "your polytheism, you will come to know how it will end up you in Hellfire"(p.780). By referring to Ali's translation, he doesn't assume that explicitly. He preferred implicitness to rendering the meaning explicitly. Also, He doesn't convey the secondary meaning of "threat and warning" clearly through creating an illocutionary act into the target language and consequently the receiver probably gets confused.

Verse No (3)

$$
\text { ( الروم-34) }
$$

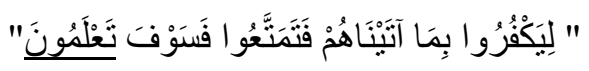

Transliteration: Liyakfuroo bima ataynahumfatamattaAAoo fasawfa taAAlamoon.

Yusuf Ali: (As if) to show their ingratitude for the (favours) We have bestowed on them! Then enjoy (your brief day); but soon will ye know (your folly).

In verse no (34) of Chapter Ar-Room, the verb (تَعَلَمُونَ ) / taAAlamoon / " know" Ali assumed the implied meaning explicitly. He assumes it as (your folly). In Tafseer Al-Jalalayn (2007), it is assumed as "the outcome of what your enjoyment"(p.1169-70). According to Ibn Katheer (2009), "warning and threat the outcome of what they have done as enjoyment"(p.1673). Adopting the speech act theory and not assuming the meaning expliciltly leads to generate two different meanings, confuses receivers, and creates negative opinions towards the source text of the Quran. That is why it shouldn't be the best option for translators. On the contrary, assuming the implied meaning of the investigated verb explicitly is more useful.

Verse No (4)

( الصافات-170)

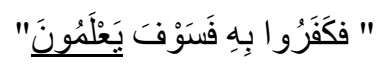

Transliteration: Fakafaroo bihi fasawfa yaAAlamoon.

Yusuf Ali: But (now that the Qur'an has come), they reject it: But soon will they know!

In verse no (170) of Chapter As-Saffat, the implied meaning of the verb (يعلمون) / yaAAlamoon/ " know" isn't declared by Ali's translation. "This indeed is a stern warning and ultimate threat for their disbelief in their Lord Glorified and Almighty and their denial and rejection of the messenger PBUH" Ibn Katheer, 2009, p.1862). The implied meaning is assumed as "the consequence of their disbelief" (Tafseer Al-Jalalayn, 2007, p.1298). The researcher thinks that some receivers might deduce this meaning, but most of them as low-context culture members of Arabic need more interpretation. Therefore, creating an explicit and performative utterance will be a good choice for translators. 
Verse No (5)

(غافر-70)

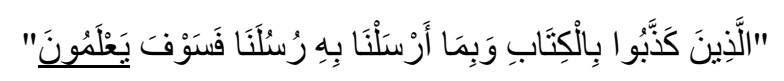

Transliteration: Allatheena kaththaboo bilkitabiwabima arsalna bihi rusulana fasawfayaAAlamoon.

Yusuf Ali: Those who reject the Book and the (revelations) with which We sent our messengers: but soon shall they know...

In verse no (70) of Chapter Ghafir, Ali hasn't assumed the implied meaning in the verb ( نَعْلَمُونَ) / yaAAlamoon /. Its meaning is assumed by Tafseer Al-Jalalayn (2007) as "they will have then known the punishment for their belying and rejecting faith and their disbelief in the oneness of Allah"(p.1359). "This indeed a stern threat and warning from the Lord"(Ibn Katheer, 2009, p.1958). However, the threat and warning aren't implied in the meaning of the verse by Ali. The verse is translated by Ali as (but soon shall they know).in his translation, Ali tends to function the speech acts; illocutionary and perlocutionary. He neither delivered the meaning of the threat and warning nor he affected the readers.

Verse No (6)

(الزخرف-89)

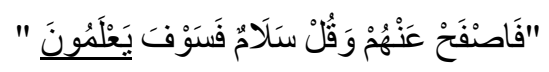

Transliteration: Fasfah AAanhum waqulsalamun fasawfa yaAAlamoonon.

Yusuf Ali: But turn away from them, and say "Peace!" But soon shall they know!

In verse no (89) of Chapter Az-Zukhruf, regarding the following expressions: "But soon shall they know!", is a promise or warning? Answers may vary, but according to Ibn Katheer (2009) "this indeed is a threat from Allah to them, hence He seized them with His Irresistible Vengeance"(p. 2038). By assuming the implied meaning of the investigated verb, the meaning of the threat and warning appears. The researcher wants to draw attention to that translation is for the meaning of the Holy Quran, not to its linguistic structures. Therefore, translators shouldn't be afraid of creating long texts as they convey the meaning comprehensibly.

Verse No ( 7 )

( البقرة - (280)

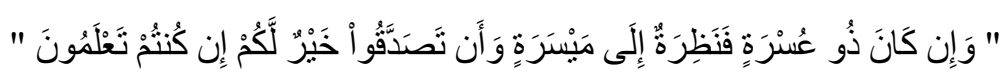

Transliteration: Wa-in kana thoo AAusratinfanathiratun ila maysaratin waan tasaddaqookhayrun lakum in kuntum taAAlamoon.

Yusuf Ali: If the debtor is in a difficulty, grant him time Till it is easy for him to repay. But if ye remit it by way of charity, that is best for you if ye only knew.

In verse no (280) of Chapter Al-Baqara, the translator hasn't delivered the meaning of the inducement and fascinating of the verb ( تعلمون )/taAAlamoon/" know", as assumed by Ibn Katheer (2009) ( فضل و عظمة ثو اب الصدقة) (the greatness and reward of charity). The researcher thinks that assuming the implied meaning explicitly delivers the illocutionary function of the translated text and consequently its influence. Translators might criticize the idea of assuming implied meanings by claiming that it will generate very long and boring translations. The researcher sees that when translating the meaning of Quran, concision and brevity are not considered the core of translation but rendering meaning explicitly and perfectly. 
Table 3. Threatening and warning chapters and verses

\begin{tabular}{lll}
\hline Serial & Chapter & Verse No \\
\hline 1 & Alanaam & 67 \\
2 & Al- Araf & 123 \\
3 & At-Tawba & 11,105 \\
4 & Al-Hijr & 3 \\
5 & Al-Nahl & 55 \\
6 & Al-Ankaboot & 66 \\
7 & Ar-Room & 34 \\
8 & Ghafir & 70 \\
9 & Az-Zukhruf & 89 \\
10 & As-Saffat & 170
\end{tabular}

Names of Quran chapters and numbers of verses that carry commissive illocutionary acts "threatening and warning" implied in the investigated verb "know" (يَعَلَمُونَ) /yaAAlamoon/ among the investigated verses

Table 4. Inducement and fascinating chapters and verses

\begin{tabular}{lll}
\hline Serial & Chapter & Verse No \\
\hline 1 & Al-Baqara & 103,216 \\
2 & Alanaam & 67 \\
3 & At-Tawba & 41 \\
4 & Al-Nahl & 95 \\
5 & Al-Jumua & 9 \\
\hline
\end{tabular}

Names of Quran chapters and numbers of verses that carry commissive illocutionary acts "inducement and fascinating" implied in the investigated verb "know" (يَعَلَكُونَ) /yaAAlamoon/ among the investigated verses

\subsection{Expressives}

"Expressive speech acts express the speakers feelings about themselves or the world" (Searle ,1976, p. 12). "Expressive speech acts express psychological conditions, and thus not beliefs or intentions, which arise to given states of affairs"(Norrick, 1978, p. 279). There are nine different kinds of expressive illocutionary acts as follows: apologizing, thanking, congratulating, condoling, welcoming, forgiving, boasting, deploring, or censoring, and lamenting.

Verse No (1) 


\section{MInstitute Machin $_{\text {Int }}$}

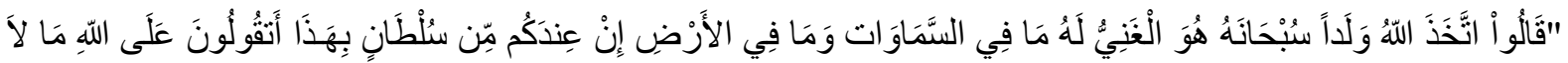
(يونس- (68)

Transliteration: Qaloo ittakhatha Allahuwaladan subhanahu huwa alghaniyyu lahu ma fee assamawatiwama fee al-ardi in AAindakum min sultaninbihatha ataqooloona AAala Allahi malataAAlamoon...

(Yunus-68)

Yusuf Ali: They say: "Allah hath begotten a son!" - Glory be to Him! He is self-sufficient! His are all things in the heavens and on earth! No warrant have ye for this! say ye about Allah what ye know not?

In verse 68 of Yunus Chapter, according to Ibn-Katheer (2009), the implied meaning of the investigated verb carries deploring, denial or questioning meaning. Apparently, the researcher doesn't face any difficulty in translating such expressive acts because the meaning is clearly delivered.

\subsection{Declaration}

This act is used to uphold a particular speech act that affects immediate changes in the institutional state of affairs and which tend to rely on elaborating extra linguistic institution as declaring war, excommunication, christening, appointing, and firing from employment. Declarative illocution is a form of speech that connects the contents of speech with reality. The investigated verb has no declarative acts to perform. Although the study covers a wide range of data, no verse could be proved carries a declarative act causing immediate changes. However, it is recommended for other researchers to consult other exegeses to conduct more studies in this area.

\section{Conclusion}

Based on the results of the data analysis of illocutionary speech acts used by Yusuf Ali in his translation of the meaning of Quran, the study has found out the following:

1) There are four functions found in the implied meaning of the verb "know" (يَعْلَمُونَ) "yAAlamoon" in the investigated verses. The four functions are directive, assertive, expressive, and commissive. Of the four functions, the commissive function is used most frequently.

2) Yusuf Ali has succeeded in delivering the representative illocutionary functions in some situations and failed in others.

3) Yusuf Ali has delivered directive, and expressive functions clearly, but he has faced some difficulties in delivering the commissives.

Based on the conclusions above, the researcher recommends some suggestions for the development of better translation.

1) The Quran translators are obliged to consult genuine and reliable exegeses to arrive at appropriate semantic and textual relatedness and to remain faithful to the meaning of the original text.

2) The use of annotated explanations is required even if they are likely to impede the naturalness of the translated text. The researcher suggests that the loss of the implied meaning of verb "know" (يَعْلَمُونَ) ) "yAAlamoon" can be put and clarified in two brackets. 


\section{Macrothink}

Education and Linguistics Research

ISSN 2377-1356 2020, Vol. 6, No. 1

3) It is a fact that the effect of the translated text on the target audience will never match the effect of the original on the source audience for a simple reason that the Divine effect cannot be challenged. Therefore, it would be helpful if the translator tries to translate the words of Allah in such a way that the translation looks straightforward and easily comprehensible.

4) One goal of the translation of Glorious Quran meanings is to deliver Islamic provisions and convince non-Muslims to enter Islam. For this reason, a translator should assume the implied meaning to provide an explicit, highly acceptable and highly informative translation.

\section{Appendix}

Transliteration System. A transliteration table used by the Calgary Islamic school

\begin{tabular}{|c|c|c|}
\hline ن & $\mathrm{N} / \mathrm{n}$ & Nurse \\
\hline g & oo & Pool \\
\hline أ & o & On \\
\hline ق & Q & Queen \\
\hline$\jmath$ & $\mathrm{R}$ & Rabbit \\
\hline 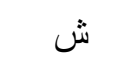 & $\mathrm{Sh}$ & Ship \\
\hline 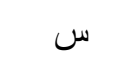 & S & Sea \\
\hline ص & $\underline{\mathrm{S}}$ & heavy "s" keep lips slightly round \\
\hline$ت$ & $\mathrm{~T}$ & Tan \\
\hline b & $\underline{\mathrm{T}}$ & heavy "t" with an open jaw but keep the lips slightly round \\
\hline 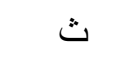 & $\mathrm{Th}$ & Think \\
\hline$\dot{~}$ & $\underline{\text { Th }}$ & The \\
\hline ظ & $\underline{\text { Th }}$ & sound like "the" but heavier with an open jaw and the lips slightly round \\
\hline ضمة & $\mathrm{U}$ & Put \\
\hline 9 & $\mathrm{~W}$ & Water \\
\hline أ $+\varsigma$ & l & pronounce the letter before but cut it short by stopping suddenly \\
\hline ي & Y & Yes \\
\hline j & $\mathrm{Z}$ & Zebra \\
\hline فتحة أ & A & About \\
\hline i & $\underline{\mathrm{A}}$ & Cat \\
\hline$\varepsilon$ & AA & say "a" twice distinctly with an open mouth \\
\hline ب & $\mathrm{B}$ & Box \\
\hline$د$ & $\mathrm{D}$ & Door \\
\hline 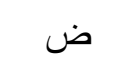 & $\underline{\mathrm{D}}$ & heavy "d" with an open jaw but keep slightly round. \\
\hline ي & $\mathrm{Ee}$ & Feet \\
\hline
\end{tabular}


ف $\mathrm{F}$

Fish

$\dot{\varepsilon}$ Gh the sound you make when you gargling (touch the very back of the tongue to the very back of mouth

$\rightarrow \quad \mathrm{H}$

Hat

$\tau \quad \underline{H}$ heavy "h" sound (drop the back of tongue to the open back of the throat, then force air out for "h")

إ كسرة I

Ink

ج $\mathrm{J}$

Jar

5) $\mathrm{K}$

Kit

$\dot{\tau} \mathrm{Kh}$ gravely "h" sound ( touch the back of tongue to the roof of mouth and force air

」L

Look

? $\mathrm{M}$

Man

\section{References}

Ali, A. Y. (Trans.). (1968). The Holy Qur'an, text, translation and commentary. Beirut, Lebanon: Dar al AArabia. (Original work published 1938).

Al-Farisi, M. (2018). Directive illocutionary act used in Al-Quran- Surah Ali-Imran (Bachelor's thesis). State Islamic University of Sunan Ampel Surabaya, Faculty of Arts and Humanities, Malaysia.

Al-Mahaly, A. J and As-Soyuty, A. J. Translation, Muhmammad Anees Gad Khaleel. (2007). Tafseer Al-Jalalayn - Volume 1. Dar Al-Manarah for translation, publishing and distribution, El-Mansoura- Egypt.

Austin, J. (1962). How to do things with words. London: Oxford University Press.

Bell, T. (1991). Translation and Translating. New York: Longman.

Brown, G., \& Yule, G. (1983). Discourse Analysis. Cambridge: Cambridge University Press.

Cutting, J. (2002). Pragmatics and discourse. London: Routledge.

Fahad, M. (1995). Performative Utterances: Their Basic \& Secondary Meanings with Reference to Five English Translations of the Meanings of the Holy Quran. Unpublished Ph.D Diss. Durham University.

Griffiths, P. (2006). An Introduction to English Semantics a Pragmatics. Edinburg: Edinburg University Press.

Hatim, B., \& Mason, I. (1997). The Translator as Communicator . London : Routledge .

Ibn Katheer, E. (2009). Translation, Muhmammad Anees Gad Khaleel -Tafseer Ibn Katheer (Abridged), (vol): 2. Dar Al-Manarah for Translation, Publishing and Distribution, El-Mansoura- Egypt. 


\section{Macrothink}

Education and Linguistics Research

ISSN $2377-1356$ 2020, Vol. 6, No. 1

Kadhim, M. (2007). The Semantics, Pragmatics and Translation of Speech Acts. Al-Mustansiriya University, Journal of the College of Basic Education, 10.

Leech, G. N. (1983). Principles of pragmatics. London: Longman.

Mey, J. L. (2001). Pragmatics: An introduction. Oxford: Blackwell Publishing.

Mustafa, M. (2019). An Investigation into the Assumptions of Elliptic Object Meaning in Translation of Glorious Quran ( Doctorate's thesis). University of Gezira, Wad Medani, Sudan.

Nida, E. (1964). Toward a science of translating. Leiden: E.J. Brill.

Norrick, N. (1978). Expressive Illocutionary Acts. Journal of Pragmatics, 2(3). https://doi.org/10.1016/0378-2166(78)90005-X

Peccei, J. S. (2005). Pragmatics Language Workbooks. New York: Routledge.

Searle, J. (1976). A classification of Illocutionary Acts. California: University of California.

Searle, J. R. (1969). Speech acts. Cambridge: Cambridge University Press.

Searle, J. (1968). Austin on Locutionary and Illocutionary Acts. Philosophical Review, 77(4), 405-424.

Shuttelworth, Mark-Cowie, M. (2007). Dictionary of translation studies. Manchester, St. Jerome Publishing.

Yule, G. (1996). Pragmatics. Oxford: Oxford University Press.

\section{Copyright Disclaimer}

Copyright reserved by the author(s).

This article is an open-access article distributed under the terms and conditions of the Creative Commons Attribution license (http://creativecommons.org/licenses/by/3.0/). 